\title{
INSTRUMEN REKOMENDASI DPRD DALAM PENYELENGGARAAN KEWENANGAN PERIJINAN OLEH PEMERINTAH DAERAH
}

\author{
Oleh : \\ Made Jayantara*
}

\begin{abstract}
Recommendation of the Local House of Representative (DPRD) is a common administrative institution employed in the local government decision making process. However, this institution does not recognized by the law. Hence, its presence dan used in the process of decision of public license contains various problem, such as: (1) its status under the administrative law; (2) its implication to the validity of the license; (3) and the position of the head of the local government, the degree of the local government responsibility as the recommendation receiver and the DPRD as the recommendation giver to the negative impact of the license. These facts resulted in needs for conducting research for clarifying the status, measuring the implication of the recommendation over the validity of the license, and the range of responsibility head of the local government and the DPRD to the impact of the license.
\end{abstract}

This research is focused into two issues, namely: (1) how is the position and function of the DPRD in the process of issuing of license; and (2) how would be the implication of the DPRD's recommendation over the range of responsibility of the head of the local government and DPRD in the issuing of license. This research is limited to the practice of issuing of recommendation in the Local Government Province of Bali.This research shall employ normative approach and uses both primary and secondary legal resources.

The research resulted in two inventions: firstly, recommendation of DPRD is not recognized by the law in the level of province local government neither it's the authorithy of the DPRD on supervising the governor. The recommendation recognized by law is the recommendation as an administrative legal instrument in the performance of local government by the governor, particularly for performing the function of decision making or the conducting of governmental act. Hence, recommendation of DPRD is a state custom in performing state governmental function. Secondly, recommendation has two functions, namely: a condition and confirmation. In the function of condition, recommendation is a prerequisite for adopting public decision. In the function of confirmation, recommendation is a merely an expression of an agreement provided by a certain instution for adopting a public decision. Recommendation in the function of condition, binds the recommendation giver to bear responsibility over the result of the implementation of the decision. While, in the function of confirmation the giver may not necessarily responsible to the result of the performance of the decision. However, under the principle of good faith, the giver is under obligation to bear responsibility over the result of the implementation of the decision whenever the recommendation is given under a bad faith.

Keywords : legal status, function, Recommendations DPRD, Authority, Licensing.

* Mahasiswa Program Magister Ilmu Hukum Program

Pascasarjana Universitas Udayana. 


\section{Pendahuluan}

\subsection{Latar Belakang Masalah}

Instrumen rekomendasi DPRD tidak dikenal di dalam peraturan perundangundangan. Instrumen ini tidak dijumpai dalam seluruh undang-undang yang mengatur pemerintahan daerah, mulai dari Undang-Undang Nomor 5 Tahun 1974, Undang-Undang Nomor 22 Tahun 1999, Undang-Undang Nomor 32 Tahun 2004 sampai dengan Undang-Undang Nomor 23 Tahun 2014. Namun dalam praktek penyelenggaraan pemerintahan, khususnya proses penetapan keputusan publik, lembaga ini merupakan instrumen nyata yang nyata digunakan dalam proses penetapan keputusan publik, terutama perizinan. Undang-Undang Nomor 30 Tahun 2014 tentang Administrasi Pemerintahan juga tidak mengenal instrumen ini. Istilah rekomendasi secara resmi digunakan dalam Peraturan Presiden Nomor 97 Tahun 2014 Tentang Penyelenggaraan Pelayanan Terpadu Satu Pintu (Perpres PTSP 2014) dan Peraturan Kepala Badan koordinasi dan Penanaman Modal Asing Nomor 12 tahun 2009 tentang Pedoman dan Tata Cara Permohonan Modal, tetapi rekomendasi yang diatur di dalam kedua regulasi dimaksud dalam rekomendasi yang dipersiapkan oleh instansi teknis (Satuan Kerja Perangkat Daerah-SKPD) sebagai sub kelembagaan pemerintah daerah untuk kepentingan kepala daerah dalam menerbitkan izin, bukan rekomendasi DPRD untuk penerbitan izin oleh kepada daerah.

Fakta ini menunjukkan bahwa instrumen rekomendasi DPRD merupakan instrumen yang berada di dalam praktek ketatanegaraan, tetapi tidak tercakupkedalam atau berada di luar peraturan perundang- undangan yang mengatur penyelenggaraan proses keputusan public, termasuk perizinan. Fakta ini juga menunjukkan bahwa kehadiran instrumen rekomendasi DPRD di dalam proses perizinan mengandung berbagai masalah hukum, seperti: (1) statuslembaga ini dari perspektif hukum administrasi; (2) implikasi penggunaannya sebagai bagian proses penerbitan izin terhadap validitas izin yang dihasilkannya; dan (3) posisi kepala daerah terhadap rekomendasi itu, derajat tanggungjawab kepala daerah sebagai penerima rekomendasi dan DPRD sebagai pemberi rekomendasi terhadap akibat yang timbul dari akibat pelaksanaan izin yang diterbitkan berdasarkan suatu rekomendasi DPRD.

Kasus penerbitan izin reklamasi Teluk Benoa, sebagaimana diterbitkan oleh Gubernur Bali, Keputusan Gubernur Bali Nomor 1727/01-B/HK/2013 tentang Pemberian Izin Study Kelayakan Rencana Pemanfaatan, Pengembangan dan Pengelolaan Wilayah Perairan Teluk Benoa, yang didasarkan pada Rekomendasi Dewan Perwakilan Rakyat Daerah (DPRD) Provinsi Bali Nomor 900/2569/DPRD, tertanggal 12 Agustus 2013, hal Peninjauan Ulang dan/ atau Pencabutan Surat Keputusan Gubernur Bali Nomor 2138/02-C/HK/2012 (tentang pemberian izin oleh Gubernur Bali yang memakai Rekomendasi DPRD Provinsi Bali Nomor660/4278/DPRDtanggal20Desember 2012 sebagai salah satu dasar pertimbangan pemberian izin), memperkuat asumsi tentang masalah hukum yang terkandung di dalam rekomendasi DPRD itu, terutama berkaitan dengan potensi akibat merugikan yang terkandung di dalam suatu izin yang diterbitkan. Dalam realita, penerbitan izin 
oleh Gubernur itu telah melahirkan pro dan kontra masyarakat tentang isi perizinan, sehingga berpotensi melahirkan konflik horizontal sekiranya izin tersebut sungguhsungguh dilaksanakan. Pro dan kontra tersebut mengakibatkan pelaksanaan izin itu tertunda, sehingga dari sisi penyelenggaraan proses keputusan publik berdasarkan Asasasas Umum Pemerintahan yang Baik (AAUPB) penerbitan izin menimbulkan keadaan yang terbalik dengan asas-asas tersebut. Bagi masyarakat dan pemohon izin proses penerbitan izin demikian itu menimbulkan ketidakpastian hukum.

Dari sisi akademik, fakta itu menggambaran kebutuhan yang mendesak terhadap penelitian tentang keberadaan instrumen rekomendasi DPRD dalam proses perizinan dalam rangka mengklarifikasi status, mengukur implikasinya terhadap validitas izin yang diterbitkan berdasarkan lembagaitu, danrentang batas tanggungjawab kepala daerah sebagai penerima rekomendasi dan DPRD sebagai pemberi rekomendasi terhadap segala akibat yang ditimbulkan oleh pelaksanaan izin yang diterbitkan berdasarkan rekomendasi itu.

\subsection{Rumusan Masalah}

1. Bagaimanakah kedudukan dan fungsi DPRD dan penyelenggaraan penerbitan perizinan?

2. Bagaimanaimplikasi rekomendasi DPRDterhadap tanggungjawab kepala daerahdan DPRD dalam penerbitan izin?

\subsection{Tujuan Penelitian \\ 1.3.1 Tujuan Umum}

Secara Umum, penelitian ini bertujuan untuk meneliti status instrumen rekomendasi DPRD dalam proses perizinan dan implikasinya terhadap luasan tanggungjawab gubernur sebagai penerima rekomendasi dan DPRD sebagai pemberi rekomendasi terhadap akibat-akibat yang timbul dari akibat pelaksanaan suatu izin yang diterbitkan oleh gubernur berdasarkan rekomendasi DPRD tersebut.

\subsubsection{Tujuan Khusus}

Secara khusus penelitian ini bertuju-an untuk mengungkapkan:

(1) Konsep hukum rekomendasi dankedudukan serta fungsi DPRD dan penyelenggaraan perizinan.

(2) Meneliti implikasi rekomendasi DPRD terhadap luasan tanggungjawab gubernur dan DPRD dalam penerbitan izin terhadap akibat-akibat yang timbul dari akibat pelaksanaan suatu izin yang diterbitkan berdasarkan rekomendasi DPRD.

\section{Metode Penelitian}

Penelitian ini merupakan jenis penelitian hukum normatif. Bahan hukum yang digunakan mencakup bahan hukum primer, seperti: undang-undang, peraturan pemerintah, dan izin, dan bahan-bahan hukum sekunder, seperti: buku, kamus, jurnal, dan bahan hukum sekunder lainnya. Teknik pengumpulan bahan hukum menggunakan teknik penelusuran kepustakaan berdasarkan variable masalah dan seterusnya menggunakan teknik kualifikasi, klasifikasi perpustakaan dan 
dokumen. Teknik analisis yang digunakan adalah teknik analisis deskriptif, termasuk: teknik diskripsi, teknik interpretasi, teknik evaluasi, teknik argumentasi, dan teknik sistematisasi. ${ }^{1}$

\section{Hasil dan Pembahasan}

\subsection{Kedudukan dan Fungsi DPRD dan Penyelenggaraan Perizinan}

Undang-undang Nomor 23 Tahun

2014 Tentang Pemerintahan Daerah (UU Pemda)menempatkan Dewan Perwakilan Rakyat Daerah (DPRD) sebagai salah satu komponen utama pemerintahan daerah. DPRD adalah lembaga perwakilan rakyat yang berkedudukan sebagai unsur penyelenggara pemerintah daerah.Fungsi DPRD berdasarkan ketentuan Pasal 96 UU Pemda, mencakup: (a) pembentukan Perda provinsi; (b) anggaran; dan (c) Pengawasan.

Berdasarkan Pasal 10 UU Pemda, fungsi pengawasan yang dilakukan oleh DPRD diwujudkan dalam bentuk pengawasan terhadap: (a) pelaksanaan Perda provinsi dan peraturan gubernur; (b) pelaksanaan peraturan perundang-undangan lain yang terkait dengan penyelenggaraan Pemerintahan Daerah provinsi; dan (c) pelaksanaan tindak lanjut hasil pemeriksaan laporan keuangan oleh Badan Pemeriksa Keuangan.Fungsi pengawasan DPRD bersifat pengawasan politik dan kebijakan, bukan pengawasan teknis fungsional.

Pasal 101 UU Pemda menentukan bahwa tugas dan wewenang DPRD provinsi, mencakup: (a) membentuk Perda Provinsi

Program Studi Magister (S2) Ilmu Hukum Program Pasca Sarjana Universitas Udayana, Loc. Cit, hlm.3435. bersama gubernur; (b) membahas dan memberikan persetujuan Rancangan Perda Provinsi tentang APBD Provinsi yang diajukanoleh gubernur; dan(c)melaksanakan pengawasan terhadap pelaksanaan Perda Provinsi dan APBD provinsi. Ketentuan Pasal 101 huruf c UU Pemda menentukan bahwa salah satu tugas dan wewenang DPRD provinsi adalah melaksanakan pengawasan terhadap pelaksanaan Perda Provinsi. Dalam melaksanakan pengawasan itu, DPRD secara melembaga dilengkapi dengan hak-hak DPRD. Pasal 106 UU Pemda menentukan bahwa hak DPRD mencakup: (a) hak interpelasi; (b) hak angket; dan (c) hak menyatakan pendapat.UU Pemda tidak menentukan hak, tugas, dan kewenangan DPRD untuk menggunakan rekomendasi sebagai instrumen pengawasan, termasuk dalam penyelenggaraan fungsi perizinan oleh Pemerintah Provinsi.Tugas, kewenangan, dan hak DPR untuk menggunakan lembaga rekomendasi dalam penyelenggaraan pemerintahan daerah juga tidak dijumpai di dalam Undang-Undang Nomor 5 Tahun 1974 tentang Pokok-Pokok Pemerintahan Di Daerah dan Undang-Undang Nomor 22 Tahun 1999 tentang Pemerintahan Daerah. Undang-Undang Nomor 30 Tahun 2014 tentang Administrasi Pemerintahan (UUAP) bahkan menentukan bahwa kewenangan mengambil keputusan merupakan hak pejabat pemerintahan.

Pengawasan Legislatif adalah pengawasan yang dilaksanakan oleh lembaga legislatif (DPRD). Hal ini termaktub secara tegasdalamUndang-UndangNomor 17Tahun 2014 tentang Majelis Permusyaratan Rakyat (MPR), Dewan Perwakilan Rakyat (DPR RI), Dewan Perwakilan Daerah (DPD) dan 
Dewan Perwakilan Rakyat Daerah (DPRD) maupun dalam Undang-Undang Nomor 23 Tahun 2014 tentang Pemerintahan Daerah. Pengawasan legislatif dilakukan melalui dengar pendapat, kunjungan kerja, dan pembentukan panitia khusus (Pansus) atau panitia kerja (Panja). Bila dianggap penting, DPRD dalam melakukan pengawasan dapat mengambil tindakan politik berupa pemanggilan Kepala Daerah, Hak Interplasi dan Hak Angket. DPRD dalam menjalankan fungsidapat menempatkan diri sebagai public service watch. ${ }^{2}$

Kewenangan pengawasan DPRD terserap penuh kedalam tugas, kewenangan, dan hak, serta kewajiban yang oleh undangundang dibebankan kepadanya, sehingga dalam melaksanakan pengawasan, DPRD tidak lagi memiliki instrumen hukum lain, termasuk rekomendasi, selain yang telah ditentukan peraturan perundang-undangan, yaitu peraturan daerah yang diakhiri dengan pertanggungjawaban gubernur. Peraturan perundang-undangan itu menunjukkan bahwa lembaga rekomendasi DPRD tidak merupakan instrumen pengawasan yang ditentukan oleh undang-undang, sehingga kehadirannya dalam penyelenggaraan pemerintahan daerah lembaga ini lebih merupakan konvensi ketatanegaraan.

Posisi rekomendasi DPRD sebagai bentuk konvensi ketatanegaraan membuat lembaga ini perlu diberi perhatian khusus dari segi keilmuan ilmu hukum, demikian juga dari sisi norma hukum, agar keberadaannya menjadi lebih jelas dan tidak kabur secara normatif. Penegasan posisi

Ibid, hlm.9. lembaga rekomendasi DPRD ini didalam penyelenggaraan pemerintahan daerah bertujuan untuk menentukan secara pasti kapan lembaga tersebut dapat digunakan dan dalam rentang tanggungjawab yang bagaimana. Kekosongan pengaturan rekomendasi DPRD dalam mekanisme penyelenggaraan pengawasan DPRD terhadapkepaladaerahdapatmemicuproblem hukum dalam penyelenggaraan kewenangan DPRD dan kepala daerah, terutama dalam hubungan dengan: (a) Keabsahan dan daya ikat suatu rekomendasi terhadap tindakan kepala daerah; (b) Keharusan kepala daerah memperhatikan atau mentaati rekomendasi; (c) Keabsahan keputusan kepala daerah yang diambil berdasarkan rekomendasi; (d) Rentang tanggungjawab kepala daerah sebagai penerima rekomendasi terhadap akibat-akibat yang ditimbulkan oleh pelaksanaan keputusan kepala daerah yang ditetapkan berdasarkan rekomendasi DPRD; dan (e) Rentang tanggungjawab DPRD sebagai pihak pemberi rekomendasi dan kepala daerah sebagai penerima rekomendasi dan pengambil keputusan berdasarkan rekomendasi terhadap akibat-akibat perbuatan pemerintahan yang dilaksanakan berdasarkan rekomendasi itu.

\subsection{Implikasi Rekomendasi DPRD Terhadap Tanggungjawab Kepala Daerahdan DPRD Dalam Penerbitan Izin}

Izin merupakan instrumen yuridis yang berbentuk ketetapan, yang digunakan oleh pemerintah dalam menghadapi peristiwa konkret dan individual. Pada umumnya wewenang pemerintah dalam menerbitkan izin ditentukan secara tegas di dalam 
peraturan perundang-undangan yang menjadi dasar dari perizinan tersebut. Tetapi dalam penerapannya, kewenangan pemerintah dalam penerbitan izin bersifat diskresionare power atau merupakan kewenangan bebas, dalam arti bahwa pemerintah dalam menerbitkan izin oleh peraturan perundangundangan diberikan kewenangan untuk mempertimbangkan dasar, materi, dan tujuan penerbitan izin berdasarkan inisiatif sendiri, misalnya pertimbangan tentang: (1) kondisi-kondisi yang memungkinkan pemberian izin kepada pemohon; (2) cara mempertimbangkankondisi-kondisitersebut; (3) konsekuensi yuridis yang mungkin timbul akibat pemberian atau penolakan izin dikaitkan dengan pembatasan peraturan perundang-undangan yang berlaku; dan (4) prosedur yang harus diikuti atau dipersiapkan pada saat dan sesudah keputusan diberikan, termasuk penerimaan maupun penolakan izin. ${ }^{3}$

Izin sebagai salah satu bentuk keputusan dari pemerintah harus memenuhi syarat-syarat sebagaimana ditentukan di dalam Pasal 52 UUAP, yaitu:

(1) Syarat sahnya Keputusan meliputi:

a. ditetapkan oleh pejabat yang berwenang;

b. dibuat sesuai prosedur; dan

c. substansi yang sesuai dengan objek Keputusan.

(2) Sahnya Keputusan sebagaimana dimaksud pada ayat (1) didasarkan

Markus Lukman, Eksistensi Peraturan Kebijakan Dalam BidangPerencanaan dan Pelaksanaan Rencana Pembangunan Di Daerah Serta Dampaknya Terhadap Pembangunan Materi Hukum Tertulis Nasional, Disertasi, Universitas Padjajaran, Bandung, hlm.189. pada ketentuan peraturan perundangundangan dan Asas-asas Umum Pemerintahan yang Baik (AUPB).

Pasal 54 UUAP menentukan bahwa suatu keputusan pemerintahan mencakup dua sifat, yaitu: (a) konstitutif dan (b) deklaratif. Keputusan yang bersifat deklaratif menjadi tanggung jawab Pejabat Pemerintahan yang menetapkan Keputusan yang bersifat konstitutif. Setiap Keputusan harus diberi alasan pertimbangan yuridis, sosiologis, dan filosofis yang menjadi dasar penetapan Keputusan. Pemberian alasan tidak diperlukan jika Keputusan tersebut diikuti dengan penjelasan terperinci. Ketentuan tersebut berlaku juga dalam hal pemberian alasan terhadap keputusan Diskresi (Pasal 55 UUAP). Pasal 56 UUAP menentukan bahwa Keputusan yang tidak memenuhi persyaratan sebagaimana diten-tukan di dalam Pasal 52 ayat (1) huruf a UUAP, tidak ditetapkan oleh pejabat yang berwenang, merupakan Keputusan yang tidak sah. Keputusan dibuat tidak sesuai prosedur dan substansinya tidak sesuai dengan obyek keputusan (Pasal 52 ayat (1) huruf b dan huruf c) merupakan Keputusan yang batal atau dapat dibatalkan.

Seluruh ketentuan di dalam UUAP tidak menyinggung soal lembaga rekomendasi DPRD dalam penetapan keputusan pejabat pemerintahan, termasuk penetapan keputusan pejabat daerah. Ketentuan tersebut juga tidak menyinggung tentang korelasi lembaga rekomendasi dengan keabsahan atau sahnya suatu keputusan pemerintahan yang ditetapkan oleh pejabat pemerintahan di daerah. Ketentuan UUAP semakin menegaskan bahwa UUAP tidak menempatkan lembaga rekomendasi DPRD sebagai prasyarat penerbitan keputusan 
pemerintahan dan karena itu juga tidak menempatkan lembaga rekomendasi sebagai prasyarat sahnya atau keabsahan suatu keputusan pemerintah, termasuk perizinan.

Lembagademikianitujugatidakdikenal dalam penyelenggaraan pelayanan publik, yang mencakup kedalamnya pelayanan perizinan. Dalam rangka mendekatkan dan meningkatkan pelayanan kepada masyarakat serta memperpendek proses pelayanan guna mewujudkan pelayanan yang cepat, mudah, murah, transparan, pasti, dan terjangkau dilaksanakan suatu pelayanan terpadu satu pintu. Pelayanan terpadu satu pintu dilakukan untuk menyatukan proses pengelolaan pelayanan, baik yang bersifat pelayanan perizinan maupun yang bersifat non-perizinan. Berdasarkan pertimbangan demikian itu, pemerintah kemudian menetapkan Peraturan Presiden Republik Indonesia Nomor 97 Tahun 2014 tentang Penyelenggaraan Pelayanan Terpadu Satu Pintu (Perpres PTSP 2014). Kehadiran dan penggunaan rekomendasi DPRD dalam penyelenggaraan kewenangan kepala daerah dalam bidang perizinan justru menimbulkan keadaan-keadaan yang terbalik dengan tujuan pelayanan publik itu.

Arahan perizinan sebagaimana diatur dalam ketentuan pasal 126 Peraturan Daerah Provinsi Bali Nomor 16 Tahun 2009 tentang Rencana Tata Ruang Wilayah Provinsi Bali (Perda RTRW) pada Pasal 126 mengatur bahwa:

(1) Arahan perizinan wilayah provinsi berfungsi :

a. sebagai dasar bagi pemerintah kabupaten/kota dalam menerbitkan perizinan lebih lanjut bagi pihakpihak yang memanfaatkan ruang;
b. sebagai alat pengendali pengembangan kawasan;
c. menjamin pemanfaatan ruang sesuai dengan rencana tata ruang, peraturan zonasi, dan standar pelayanan minimal, dan kualitas minimum yang ditetapkan;
d. menghindari dampak negatif; dan
e. melindungi kepentingan umum.

(2) Arahan perizinan wilayah provinsi merupakan bentuk-bentuk izin pemanfaatan ruang yang harus mengacu pada rencana struktur, rencana pola ruang wilayah provinsi dan arahan peraturan zonasi, terdiri atas:

a. rekomendasi arahan perizinan terhadap izin pemanfaatan ruang pada kawasan strategis provinsi yang ditindaklanjuti oleh pemerintah kabupaten/kota; dan

b. izin yang menjadi kewenangan pemerintah provinsi berdasarkan peraturan perundangundangan.

(3) Gubernur menerbitkan rekomendasi arahan izin pemanfaatan ruang yang sifat media dan sebaran dampaknya bersifat lintas kabupaten/kota, dan/ atau skala provinsi.

(4) Gubernur menerbitkan rekomendasi arahan izin pemanfaatan ruang sesuai jenis dan lingkupnya, diatur lebih lanjut dengan Peraturan Gubernur.

(5) Izin pemanfaatan ruang untuk kegiatan pemanfaatan sumber daya alam diatur sesuai dengan peraturan perundangundangan.

(6) Izin pemanfaatan ruang diterbitkan oleh pejabat yang berwenang dengan mengacu pada rencana tata ruang 
wilayah, rencana rinci tata ruang, rencana detail tata ruang dan peraturan zonasi.

Seluruh ketentuan yang mengatur perizinan menempatkan urusan perizinan pemerintahan daerah provinsi sebagai urusan penuh gubernur. Ketentuan tersebut mengatur tentang persyaratan, proses, prosedur, dan tata cara penerbitan izin. Tidak satupun ketentuan diantara ketentuan yang mengatur urusan perizinan itu memberikan tempat kepada DPRD provinsi untuk memegang kewenangan atau tugas penerbitan rekomendasi dalam penerbitan izin. Kata rekomendasi pada ketentuan Pasal 126 ayat (2) huruf a Perda RTRW Bali merupakan kata yang berkorelasi dengan kewenangan gubernur terhadap pemerintah kabupaten/kota, bukan kewenangan DPRD provinsi terhadap kewenangan gubernur. Ketentuan tersebut sekali lagi menegaskan bahwa peraturan perundang-undangan yang mengatur perizinan tidak mengenal lembaga rekomendasi DPRD dalam hubungan dengan kewenangan gubernur dalam proses perizinan atau penetapan izin.

Praktek penjabaran Perpres KTSP di Provinsi Bali menunjukkan bahwa Pemerintah Provinsi Bali kembali mengacu kepada Perpres. Draft Peraturan Gubernur Bali Tahun 2015 Tentang Pelayanan Terpadu Satu Pintu ${ }^{4}$ menunjukkan bahwa penggunaan kata rekomendasi di dalam Draft Peraturan Gubernur (Pergub KTSP) itu digunakan tidak dalam korelasi dengan kewenangan pengawasan DPRD terhadap gubernur, melainkan kedudukan dan fungsi

Bahan Rapat Pembahasan Draft Peraturan Gubernur Bali Tahun 2015 TentangPenyelenggaraan Pelayanan Terpadu Satu Pintu, Juli 2015.
Tim Teknis perizinan dalam penerbitan izin. Pasal 6 ayat (1) angka 5 menentukan bahwaTim Teknis memiliki kewenangan untuk memberikan saran pertimbangan dalam rangka memberikan rekomendasi mengenai diterima atau ditolaknya suatu permohonan perizinan kepada Kepala SKPD yang secara teknis terkait dengan unit pelayanan perizinan terpadu dan Kepala SKPD yang bersangkutan. Rancangan ketentuan itu menunjukkan bahwa lembaga rekomendasi di dalam Draft Pergub itu merupakan instrumen perizinan yang digunakan oleh Tim Teknis untuk memberkan landasan teknis kepada Kepala SKPD dalam menerbitkan izin.

Pengaturan rekomendasi dalam berbagai contoh ketentuan sebagaimana diuraikan di atas menunjukkan bahwa lembaga rekomendasi digunakan untuk dua fungsi, yaitu: (1) fungsi persyaratan; dan (2) fungsi konfirmasi. Dalam fungsi persyaratan, suatu rekomendasi merupakan prasyarat penetapan suatu keputusan, sedangkan dalam fungsi konfirmasi, suatu rekomendasi hanya bersifat persetujuan oleh pihak yang memberikan rekomendasi kepada pihak yang memegang kewenangan untuk menetapkan keputusan. Secara teoritik, kedua fungsi ini menimbulkan implikasi hukum yang berbeda. Dalam fungsi persyaratan, suatu rekomendasi menempatkan si pemberi rekomendasi terikat oleh akibat-akibat yang ditimbulkan oleh tindakan atau ketetapan yang dibuat oleh pihak yang menerima rekomendasi. Sedangkan, dalam fungsi konfirmasi, si pemberi rekomendasi tidak terikat oleh akibat-akibat yang ditimbulkan oleh keputusan atau tindakan yang ditetapkan atau diambil oleh si penerima rekomendasi. Perbedaan implikasi rekomendasi 
terhadap si pemberi rekomendasi disebabkan oleh posisi si penerima rekomendasi dalam melaksanakan tindakan atau menetapkan suatu keputusan. Dalam fungsi persyaratan, si penerima rekomendasi terikat oleh rekomendasi. Perbuatan yang dilakukan atau keputusan yang ditetapkan oleh penerima rekomendasi harus sesuai atau tidak boleh bertentangan dengan isi rekomendasi. Dalam hal suatu perbuatan yang dilakukan atau keputusan yang ditetapkan berbeda atau bertentangan dengan isi rekomendasi, maka tanggungjawab terhadap akibat yang timbul dari akibat perbuatan yang dilakukan atau keputusan yang ditetapkan sepenuhnya menjadi tanggungjawab penerima rekomendasi. Rekomendasi dalam sifat demikian ini juga mengakibatkan si pemberi rekomendasi terikat untuk bertanggungjawab terhadap akibat-akibat yang ditimbulkan oleh perbuatan, tindakan yang dilakukan atau keputusan ditetapkan oleh penerima rekomendasi.

Sedangkan dalam fungsi konfirmasi, si penerima rekomendasi tidak terikat oleh rekomendasi yang diberikan oleh pemberi rekomendasi. Si penerima rekomendasi mempunyai hak atau kewenangan penuh untuk menggunakan atau tidak menggunakan pertimbangan yang diberikan oleh pemberi rekomendasi melalui rekomendasi yang diberikan itu. Si penerima rekomendasi mempunyai hak atau kewenangan penuh untuk untuk mengambil tindakan atau menetapkan keputusan berdasarkan otoritas yang ada padanya. ${ }^{5}$ Fungsi demikian itu mengakibatkan tanggungjawab terhadap segala akibat yang timbul dari perbuatan,

Jay A. Sigler, loc.cit. tindakan, atau ketetapan yang dilakukan atau diputuskan oleh penerima rekomendasi sepenuhnya berada pada si penerima rekomendasi, sementara di pemberi rekomendasi terbebas dari tanggngjawab. Namun demikian, menurut teori itikad baik, rekomendasi dalam kedua fungsi itu tetap dapatmenyeretsipemberi rekomendasi untuk mengemban tanggungjawab terhadap akibat perbuatan atau keputusan yang dialakukan atau diputuskan oleh penerima rekomendasi dalam hal rekomendasi itu diberikan tidak berdasarkan itikad baik. Asas itikad baik merupakan salah satu asas hukum umum yang telah diserap oleh UUAP. Pasal 24 UUAP meletakkan asas itikad baik sebagai salah satu syarat penggunaan diskresi.

Sekalipun konvensi ketatanegaraan di Indonesia menunjukkan bahwa lembaga rekomendasi umumnya dipergunakan dalam lingkungan eksekutif dalam penerbitan izin, namun praktek penyelenggaraan pemerintahan daerah di Bali menunjukkan bukti berbeda. Pada tertanggal 20 Desember 2012 DPRD Bali menerbitkan Rekomendasi DPRD Provinsi Bali Nomor 660/14278/ DPRD tertanggal 20 Desember 2012, tentang dukungan kepada Gubernur untuk menerbitkan izin melanjutkan feseability study oleh PT TWBI di kawasan Teluk Benoa. Berdasarkan rekomendasi tersebut, Gubernur Bali menerbitkan Keputusan Gubernur Bali Nomor: 2138/02-C/HK/2012 Tentang Izin dan Hak Pemanfaatan, Pengembangan dan Penge-lolaan Kawasan Perairan Teluk Benoa Provinsi Bali.

Terbitnya SK Gubernur itu telah menimbulkan silang pendapat dikalangan birokrat, ahli, dan masyarakat tentang perbedaan isi rekomendasi DPRD dengan 
isi Keputusan yang diterbitkan Gubernur Bali.Atas kisruh itu, DPRD Bali kembali menerbitkan Rekomendasi DPRD Provinsi Bali Nomor: 443.4/85/DPRD, tertanggal 21 Januari 2014, sebagai kelanjutan dari rekomendasi sebelumnya yaitu Rekomendasi Nomor: 900/2569/DPRD tertanggal 12 Agustus 2013 perihal: Peninjauan Ulang dan/atau Pencabutan SK Gubernur Bali Nomor: 2138/02- C/HK/2012. Rekomendasi itu tidak dapat diikuti oleh Gubernur dengan alasan SK Gubernur tentang izin reklamasi itu diterbitkan berdasarkan Rekomendasi DPRD Nomor: 900/2569/DPRD. Argumentasi Gubernur adalah bahwa pencabutan itu tidak diperlukan sekiranya saja Rekomendasi DPRD yang digunakan sebagai dasar penerbitan SK Gubernur itu dicabut oleh DPRD. Berdasarkan pandangan itu, Gubernur justru menyarankan DPRD Bali untuk mencabut Rekomendasi 900/2569. Jika Rekomendasi itu dicabut, maka SK Gubernur yang diterbitkan berdasarkan Rekomendasi itu akan gugur dengan sendirinya.

SK Gubernur 2138/1727 menjadi isu besar di Bali, di Indonesia atau bahkan masyarakat internasional. SK itu secara material berbenturan dengan berbagai peraturan perundang-undangan, seperti: Undang-Undang Nomor 26 Tahun 2007 Tentang Tata Ruang; Undang-Undang Nomor 27 Tahun 2007 Tentang Pengelolaan Wilayah Pesisir dan Pulau-Pulau Kecil (UU PW3K); Perpres Nomor 45 Tahun 2011 Tentang Tata Ruang Sarbagita (Denpasar, Badung, Gianyar, dan Tabanan), Perpres Nomor 122 tahun 2012 Tentang Reklamasi di Wilayah Pesisir (Perpres Reklamasi), dan Perda Nomor 16 tahun 2009 Tentang Tata Ruang Wilayah Bali.
Ketentuan-ketentuan tersebut menunjukkan bahwa SK Gubernur 2138 mengandung potensi besar merusak, menimbulkan akibat merugikan yang bersifat massif terhadap lingkungan hidup dan kehidupan masyarakat Bali. SK tersebut hingga saat ini belum dicabut oleh Gubernur dan tetap menjadi sumber polemik dalam kehidupan masyarakat Bali.SK Gubernur 2138 merupakan SK yang diterbitkan berdasarkan rekomendasi 300/2569 DPRD Bali. Pada kenyataannya, DPRD Bali menerbitkan rekomendasi itu berdasarkan itikad baik, yaitu dengan tujuan untuk mendukung penerbitan SK Gubernur untuk memenuhi permohonan PT TWBI untuk melanjutkan melakukan studi kelayakan di Kawasan Teluk Benoa dalam rangka pengembangan sarana dan prasarana pariwisata. Studi kelayakan itu sendiri bertujuan untuk menentukan apakah pengembangan sarana-prasarana pariwisata itu layak diselenggarakan pada kawasan tersebut. Namun, berdasarkan rekomendasi itu, Gubernur telah menerbitkan SK 2138 yang isinya berbeda dengan isi Rekomendasi DPRD, yaitu bahwa SK 2138 itu memuat izin reklamasi bagi PT TWBI. Isi SK itu, dengan demikian, tidak hanya berbeda dengan Rekomendasi DPRD, tetapi juga berbeda dengan isi permohonan PT TWBI.

Bertolak dari teori rekomendasi berdasarkan itikad baik, maka DPRD Bali tidak terikat untuk bertanggungjawab terhadap segala akibat dari penerbitan SK Gubernur 2138 itu, karena Rekomendasi DPRD itu telah diberikan berdasarkan itikad baik. Bertolak dari teori fungsi rekomendasi, Rekomendasi DPRD itu menunjukkan ciri sebagai prasyarat penerbitan SK yang 
ditetapkan Gubernur. Namun, merujuk pada ketentuan perizinan yang tidak satupun mensyaratkan rekomendasi DPRD dalam penerbitan SK Gubernur dalam penetapan izin studi kelayakan, maka fungsi prasyarat yang tampak dalam tampilan Rekomendasi DPRD merupakan fungsi prasyarat semu, karena ketentuan peraturan perundangundangan tidak mensyaratkan demikian. Kenyataan hukum ini menunjukkan bahwa DPRD tidak terikat untuk bertanggungjawab terhadap segala akibat yang ditimbulkan oleh pelaksanaan SK Gubernur yang diterbitkan oleh Gubernur. Gubernur, berdasarkan teori ini, bertanggungjawab penuh terhadap akibat yang ditimbulkan oleh pelaksanaan SK itu.

Analisis di atas menunjukkan bahwa rekomendasi DPRD merupakan lembaga kebijakan yang berada di luar peraturan perundang-undang. Penggunaan lembaga tersebut, dalam kasus SK Gubernur 2138, terbukti menimbulkan masalah tanggungjawab antara DPRD dengan Gubernur. Gubernur mengklim dirinya tidak bersalah, karena SK yang diterbitkannya didasarkan pada rekomendasi Gubernur, sementara itu DPRD lebih mudah lagi mengklim diri tidak bersalah karena tidak ada peraturan perundang-undangan yang mewajibkan Gubernur meminta rekomendasi DPR dalam penerbitan SK tersebut sehingga Gubernur seyogyanya bertanggungjawab atas keputusan yang diterbitkannya. Posisi dan akibat yang ditimbulkan oleh lembaga rekomendasi dalam praktek penyelenggaraan peme-rintahan menjadi petunjuk bahwa lembaga tersebut disamping merupakan lembaga yang berada di luar hukum juga merupakan lembaga yang mengakibatkan penye-lenggaraan pemerintahan daerah berjalan tidak efektif dan efisien sehingga keberadaannya sebagai konvensi ketatanegaraan tidak perlu dipertahankan.

Lembaga rekomendasi seyogyanya dihapuskan, dengan berpijak kepada dua alasan sebagai hasil analisis dalam penelitian ini: pertama, lembaga rekomendasi DPRD merupakan lembaga yang berada di luar pengaturan peraturan perundangundangan; dan kedua, dari sisi praktikal, lembaga tersebut mengakibatkan timbulnya ketikpastian hukum, ketidak-efektifan, dan ketidakefisienan dalam penyelenggaraan pemerintahan daerah yang bertentangan dengan asas-asas umum pemerintahan yang baik (AAUB).

\section{Simpulan dan Saran}

\subsection{Simpulan}

4.1.1 Lembaga rekomendasi DPRD pada tingkat pemerintahan provinsi tidak dikenal di dalam peraturan perundangundanganyangmengaturtentangpenyelenggaraan pemerintahan Negara dan peraturan perundang-undangan teknis lainnya. Lembaga rekomendasi DPRD dalam penyelenggaraan pemerintahan daerah juga bukan merupakan penjabaran dari kewenangan pengawasan DPRD terhadap gubernur. Lembaga rekomendasi yang dikenal di dalam peraturan perundang-undangan adalah lembaga rekomendasi sebagai instrumen hukum administrasi dalam penyelenggaraan pemerintahan oleh gubernur, khusunya dalam penyelenggaraan fungsi pene-tapan keputusan atau pelak-sanaan tindak pemerintahan. Lembaga rekomendasi DPRD dalam proses perizinan meru- 
pakan konvensi ketatanegaraan dalam penyelenggaraan peme-rintahan Negara.

4.1.2 Lembaga rekomendasi memiliki dua fungsi, yaitu fungsi persyaratan dan fungsi konfirmasi. Dalam fungsi persyaratan, rekomendasi meru-pakan persyaratan penerbitan keputusan pemerintahan. Dalam fungsi konfirmasi, rekomendasi semata-mata merupakan instru-men persetujuan tidak mengikat dalam penerbitan keputusan pemerintahan. Rekomendasi dalam fungsi persyaratan, mengikat pemberi rekomendasi untuk bertanggungjawab ter-hadap akibatakibat yang timbul dari pelaksanaan keputusan yang ditetapkan berdasarkan rekomen-dasi tersebut. Sedangkan dalam fungsi konfirmasi, pemberi rekomendasi tidak terikat untuk bertanggungjawab terhadap akibat-akibat pelaksanaan kepu-tusan yang ditetapkan dan dilaksanakan oleh penerima rekomendasi. Namun demikian, berdasarkan asas itikad baik, pemberi rekomendasi terikat untuk bertanggungjawab ter-hadap akibat penetapan dan pelaksanaan keputusan yang dilakukan oleh penerima rekomendasi dalam hal rekomendasi itu diberikan berdasarkan itikad tidak baik.

\subsection{Saran}

4.2.1 Lembaga rekomendasi DPRD sebaiknya tidak perlu digunakan lagi dalam proses penetapan keputusan atau tindak peme-rintahan daerah, mengingat lembaga ini tidak dikenal dan tidak diatur di dalam peraturan perundang-undangan, disamping ketidak pastian hukum yang ditimbulkannya. Penggunaan lembaga rekomendasi DPRD dalam praktek penerbitan izin pada Pemerintah Provinsi Bali telah menjadi sumber dan memicu kekaburan batas tanggungjawab antara DPRD dan Gubernur sebagaimana terjadi dalam kasus izin reklamasi yang diterbitkan Gubernur.

4.2.2 Lembaga rekomendasi tetap dapat digunakan sebagai instrumen perizinan internal eksekutif mengingat lembaga tersebut dikenal dan diatur di dalam peraturan perundang-undangan. Teori fungsi reko-mendasi dan asas itikad baik dapat digunakan sebagai dasar untuk mempertegas batas dan luasan tanggungjawab antara pemberi dan penerima re-komendasi.

\section{Daftar Pustaka}

Ali, Faried, dan Andi Syamsu Alam, 2012, Studi Kebijakan Pemerintah, Refika Aditama, Bandung.

Atmosudirdjo,S.Prajudi 2004, Hukum Administrasi Negara,Edisi revisi,GahliaIndonesia, Cetakan ke 10, Jakarta.

Bruggink,JJH, 1999, Refleksi tentang Hukum, alih bahasa: Sidharta,Arief, PT.CitraAditya Bakti, Bandung.

Busrizalti, 2013, Hukum Pemda Otonomi Daerah dan Implikasinya, Todal Media, Yogyakarta.

Fuady,Munir, 2013, Teori-teori besar (Grand Theory) Dalam Hukum, Kencana, Jakarta.

Goorden, 1977, Algemeen Bestuursrecht Compact, Vuga, Gravenhage. 
Hadjon, Phillipus M, 2008, Argumentasi Hukum, Gadjah Mada University Press, Yogyakarta.

Handoyo, Hestu Cipto, Otonomi Daerah Titik Berat Otonomi dan Urusan Rumah tangga Daerah, Universitas Atma Jaya, Yogyakarta.

Kelsen,Hans, 2013,Teori Umum Tentang Hukum dan Negara, Nusa Media,Bandung.

Kansil, CST, Christine dkk, 2008, Pemerintahan Daerah di Indonesia, Sinar Grafika, Jakarta.

2009, Hukum Administrasi Daerah,Jala PermataAksara, Jakarta.

Kusuma, RM AB, 2009, Lahirnya UndangUndang Dasar 1945, Badan Penerbit Fakultas HukumUniversitas Indonesia, Jakarta.

Labolo, Muhadam 2006, Memahami Ilmu Pemerintahan, PT.Rdja GrafindoPersada, Jakarta

Marzuki, Peter Mahmud, 2005, Penelitian Hukum, Kencana Prenada, Jakarta.

Marbun, SF 1997, Peradilan Administrasi Negara dan Upaya Administratif diIndonesia, Liberty, Yogyakarta.

Masud, 2008, Arah Baru Otonomi Daerah di Indonesia, UMM Press, Malang.

Michiels, 2001, Hoofdzaken van het Bestuursrecht, Kluwer, Denver.

Murhani, Suriansyah, 2008, Aspek Hukum Pengawasan Pemerintah Daerah, Laksbang Mediatama.

Program Studi Magister (S2) Ilmu Hukum Program Pasca Sarjana UniversitasUdayana, 2013, Pedoman Penulisan Usulan Penelitian Tesis dan PenulisanTesis Program Studi Magister (S2) Ilmu Hukum, Universitas Udayana, Denpasar.
Rasjidi, Lili, dan IB Wyasa Putra, 2003, Hukum Sebagai Suatu Sistem, Mandar Maju, Bandung.

Salim,H dan Nurbadi,ES, 2013, Penerapan Teori Hukum pada Penelitian Tesis danDesertasi PT.Raja Grafindo Persada, Jakarta.

Sadjijono, 2007, Memahami beberapa Bab Pokok Hukum Asdministrasi, LaksbangPressindo, Yogyakarta.

Salman S, Otje dan Anthon F. Susanto, 2009, Teori Hukum, Refika Aditama, Bandung.

Sekretariat Negara RI, 1995, Risalah Sidang Badan Penyelidik Usaha-Usaha Persiapan Kemerdekaan Indonesia, Sekretariat Negara RI, Jakarta.

Sirajuddin, dkk, 2009, Parlemen Lokal DPRD Peran dan Fungsinya dalam Dinamika Otonomi Daerah, Setara Press, Malang.

Sidharta, Bernard Arief, 2009, Refleksi Tentang Struktur Ilmu Hukum, Mandar Maju, Bandung. , 2007, Meuwissen Tentang Pengembangan Hukum, Ilmu Hukum, Teori Hukum, dan Filsafat Hukum, Refika Aditama, Bandung.

Stout,HD, 1994, De Betekenissen van de wet, EEJ,Tjeenk, Wellink, Zwollen.

Sutedi,Andrian, 2011, Hukum Perizinan dalam sektor pelayanan publik, Sinar Grafika, Jakarta.

Siglar, Jay A, 1977, The Legal Sources of Public Policy, Lexington Books, Lexington, USA.

Sunggono,Bambang, 2007, Metodelogi Penelitian Hukum, PT.Raja Grafindo Persada, Jakarta. 
Soekanto,Soerjono dan Mamudji,Sri, 2003, Penelitian Hukum Normatif, Suatu

Tinjauan Singkat, PT Raja Grafindo Persada, Jakarta.

Sunarno, Siswanto, 2009, Hukum

Pemerintahan Daerah di Indonesia, Sinar Grafika, Jakarta.

Syaukani,Imam dan Thohari,Ahsin.A, 2012, Dasar-dasar Politik Hukum, PT.RajaGrafindo Persada, Jakarta.

Utercht E./Moh.Saleh Djindang, 1983, Pengantar dalam Ilmu Hukum Indonesia,

Sinar Harapan, Jakarta.

1986, Pengantar Hukum

Administrasi Negara Indonesia, Pustaka TintaMas, Surabaya.

Widjaya, 1998, Percontohan Otonomi

Daerah di Indonesia, Rineka Cipta, Jakarta.

Wignjosoebroto, Soetandyo, 2013, Hukum:

Konsep dan Metode, Setara Press, Malang.

\section{JURNAL}

Hadjono, Philipus.M, 1998, Tentang Wewenang Pemerintahan

(Bestuurbevoegdheid, Jurnal Pro Justitia Tahun XVI No.1, Universitas ParahyanganBandung.

Syafrudin,Ateng.P, 2000, Menuju Penyelenggaraan Pemerintahan Negara yangBersih dan Bertanggung Jawab, Jurnal Pro Justisia Edisi IV, UniversitasParahyangan, Bandung.
PERATURAN PERUNDANG-

\section{UNDANGAN}

UUD NRI 1945

UU No.1 Tahun 1945 Tentang Pennyelenggaraan Otonomi Daerah

UUNo.22 Tahun 1948 TentangPemerintahan Daerah

UU No.1 Tahun 1957 Tentang Pokok-Pokok Pemerintahan Daerah

UU No.18 Tahun 1965 Tentang PokokPokok Pemerintahan Daerah

UU No.5 Tahun 1974 Tentang Pokok-Pokok Pemerintahan Daerah

UU No.22 Tahun 1999 Tentang Pemerintahan Daerah

UUN0.32 Tahun 2004 TentangPemerintahan Daerah

UU No.12 Tahun 2011 Tentang Hirarki Perundang-undangan

UU No. 17 Tahun 2014 Tentang Majelis Permusyawaratan Rakyat, DewanPerwakilan Rakyat, Dewan Perwakilan Daerah, dan Dewan Perwakilan RakyatDaerah.

UU No. 23 Tahun 2014 Tentang Pemerintahan Daerah

PERDA 16/2009 (RTRW Prov.Bali)

PERDA 27/2011 (RTRW Kota Denpasar)

\section{SURAT KEPUTUSAN}

SK Gubernur Bali No. 2138/02-C/HK/2012 (Pemberian Izin Pengelolaan)

SK Gub.Bali No.1727/01-B/HK/2013 (Izin Studi Kelayakan)

\section{SURAT REKOMENDASI}

Surat Rekomendasi DPRD Prov.Bali No.660/14278/DPRD, tgl 20.12.2012

Surat DPRD Prov.Bali No.900/2569/DPRD tgl. 12 Agustus 2013 


\section{KAMUS DAN ENSIKLOPEDI}

Black, Henry Campbell, Black's Law Dictionary, West Publishing, St. Paul Minn, USA, 1979.

Cambridge International Dictionary of English, 1995, Cmabridge University Press.

Encyclopedia of International Law, 1987, North Holland, Amsterdam.

Departemen Pendidikan dan Kebudayaan, 1991, Kamus Besar Bahasa Indonesia, Balai Pustaka, Jakarta 